\title{
Economic growth over the past twenty years
}

\section{Xiaolu Wang}

China has experienced rapid economic growth over the past twenty years of reform. Official statistics show that the average growth rate of GDP increased from 6.1 per cent during the pre-reform period (195378 ) to 9.7 per cent for the reform period of 1979-98 (State Statistical Bureau 1998; Economic Daily, January 1999). Growth of per capita GDP was around 7.8 per cent (World Bank 1996a, 1997a). ${ }^{1}$

What contributed to the acceleration of economic growth? Was the rapid growth input-driven and short-term, or sustainable over the long run? ${ }^{2}$

\section{An engine of economic growth: institutional change and rural industrialisation}

Development of China's rural industrial and other non-agricultural sectors-the township and village enterprises (TVE) sector ${ }^{3}$-played an important role during the reform period (Garnaut and Ma 1996). Employment in this sector increased by more than 100 million workers, from 28 to 130 million (1978-97), and accounted for 19 per cent of China's total labour force and 28 per cent of the rural labour force in 
1997. During the period 1978-97, the share of GDP contributed by TVE increased from 4 per cent to 28 per cent, contributing to one-third of economic growth.

The rapid growth of the TVE sector was mainly a result of institutional change that removed restrictions on factor allocation among rural sectors. Although commune and brigade enterprises (CBEs, the predecessors of TVEs) were encouraged by central policy during the pre-reform period (1958-78), development of rural industrial enterprises was under various institutional restrictions including

- production was restricted to a few agriculture-related areas

- rural enterprises had to be collectively owned; private enterprises were prohibited

- important inputs and bank funds were controlled and only guaranteed for state-owned enterprises

- geographic migration was restricted, not only from rural to urban, but also among different rural areas

- the collectives could not transfer their labour, capital, or land to nonagricultural use without fulfilling the state quota for agricultural production (LBSC 1987). ${ }^{4}$

These institutional restrictions were put in place so that agricultural products could be obtained at below-market prices to support the heavy industry priority' development strategy (Dong 1988; Lin et al. 1996a), and to protect the central-planning system from the threat of free-market competition.

Table 2.1 Comparison of growth performance in the pre-reform and reform periods (per cent)

Average growth rates

GDP
Agriculture
Industry and construction
Services
GDP per capita
Foreign trade
Exports
Imports

$1953-78$

6.1

2.1

11.0

5.5

4.0

9.5

10.0

9.1
$1979-97$

9.8

5.0

11.9

10.6

8.4

15.6

16.7

14.5

Source: State Statistical Bureau, 1998. Statistical Yearbook of China, China Statistical Publishing House, Beijing. 
Under these restrictions rural non-agricultural activities were seriously under developed in the pre-reform period. However, with the scarcity of arable land and water, labour productivity in the agricultural sector was very low.

Early agricultural reform-the introduction of the household responsibility system (HRS) in 1979-82, and abolition of the people's commune system in 1982-83-transformed the agricultural sector from collective to household-based production. Farmers had more freedom in allocating their labour to non-agricultural activities.

Another important change that occurred from 1984 onwards was an easing of discriminative policies against non-state enterprises. Most barriers to entry were removed. The ban on rural private enterprises was lifted. There was also a significant reduction in the level of central control over industrial inputs and outputs, particularly government quotas on agricultural output.

The development of TVEs accelerated significantly following institutional and policy changes. TVE employment increased by more than 12 million workers per year from 1984 to 1988 . Transfer of rural labour slowed but remained at a level of four million workers per year during the period 1989-97.

Table 2.2 Contribution to GDP by sectors (billion yuan, current prices)

\begin{tabular}{|c|c|c|c|c|c|c|}
\hline & $\begin{array}{r}19 \\
\text { Value }\end{array}$ & $\begin{array}{l}78 \\
\text { Share } \\
(\%)\end{array}$ & $\begin{array}{l}199 \\
\text { a Value }\end{array}$ & $\begin{array}{l}7 \\
\text { Share } \\
(\%)\end{array}$ & $\begin{array}{c}1979-97 \\
\text { Growth rate } \\
(\%)\end{array}$ & $\begin{array}{c}1979-97 \\
\text { Share in growth } \\
(\%)\end{array}$ \\
\hline $\begin{array}{l}\text { Urban sectors } \\
\text { State sector }{ }^{c} \\
\text { Urban non-state } \\
\text { Rural sectors } \\
\text { Agriculture } \\
\text { TVE } \\
\text { Others } \\
\text { GDP }\end{array}$ & $\begin{array}{r}235 \\
195 \\
40 \\
127 \\
102 \\
14 \\
11 \\
362\end{array}$ & $\begin{array}{r}65 \\
54 \\
11 \\
35 \\
28 \\
4 \\
3 \\
100\end{array}$ & $\begin{array}{r}3,800 \\
2,160 \\
1,640 \\
3,677 \\
1,397 \\
2,074 \\
206 \\
7,477\end{array}$ & $\begin{array}{r}51 \\
29 \\
22 \\
49 \\
19 \\
28 \\
3 \\
100\end{array}$ & $\begin{array}{r}8.4 \\
6.3 \\
13.8 \\
10.4 \\
5.0 \\
21.8 \\
9.2 \\
9.8\end{array}$ & $\begin{array}{r}52 \\
26 \\
26 \\
48 \\
10 \\
35 \\
3 \\
100\end{array}$ \\
\hline
\end{tabular}

Notes: asector's share of total GDP (GDP in the corresponding year $=100$ ).

${ }^{b}$ Average economic growth rate as 100 per cent.

'Author's estimations based on various sources from State Statistical Bureau. Source: State Statistical Bureau, 1998. Statistical Yearbook of China, China Statistical Publishing House, Beijing. 
Associated with the massive transfer of rural labour, there was also a reallocation of capital, technology and human capital from other rural and urban sectors to the TVE sector.

There was a large productivity gap between the TVE and agricultural sectors. Both the average and marginal product of labour in the TVE sector were three to four times that in agriculture (Wang 1997a). Therefore, transfer of labour increased total factor productivity (TFP) in the economy, significantly accelerating economic growth. Preliminary estimations suggest that institutional changes, and labour and capital reallocation between the agricultural and TVE sectors accelerated economic growth by 1.4 percentage points between 1980 and 1992a net contribution to economic growth of 14 per cent (Table 2.3). ${ }^{5}$

The remainder of TFP growth in the two sectors could have been the result of institutional changes that increased producers' efficiency at the firm or household level. In Table 2.3 the two effects are indicated separately. From the point of view of sectors, the contribution of factor

\section{Table 2.3 The net contribution of rural factor reallocation to economic growth (average growth rate, 1981-92, per cent)}

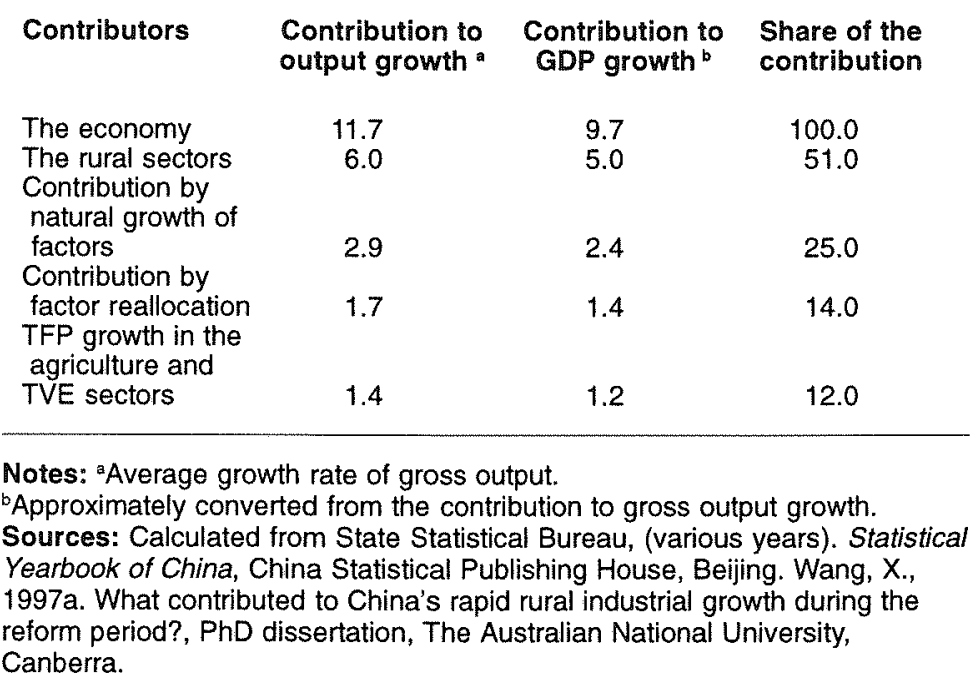


reallocation is the same as the contribution of factor growth. Only at the aggregated economy level does this effect exhibit increases in TFP. At this level the two effects-factor reallocation between sectors and TFP growth within sectors-together positively contributed to economic growth by 2.6 percentage points during the period 1981-92, as a net increase in TFP. They accelerated economic growth from 7.1 per cent to 9.7 per cent.

After twenty years of reform, the major institutional restrictions that hindered factor reallocation have been removed, and the economic benefits of reallocation of factors between rural sectors have been largely realised. The rate of agricultural labour transfer to the TVE sector has begun to decrease. Employment growth in the TVE sector was 11.1 per cent on average between 1981 and 1992, but decreased to 4.2 per cent during 1993-97. With consideration of the different natural growth rates of rural labour, employment growth in the TVE sector that was induced by cross-sector transfer of rural labour was 7.6 and 3.7 per centage points for the two sub-periods, respectively (SSB 1996:388, 1998:387, 420).

Taking this fact into account, the contribution of factor reallocation as a share of economic growth diminished from 14 per cent in the first sub-period to 8 per cent in the second sub-period. During the entire period of 1979-97 it comprised about 11 per cent of economic growth.

Similarly, excluded TFP growth in the agricultural and TVE sectors was also lower in the period 1993-98, due to the diminishing institutional effect (Wang 1997a). According to this trend, we can assume that its contribution to economic growth fell from 12 per cent in the first subperiod (Table 2.3) to between 7 and 8 per cent in the second subperiod (therefore, between 9 and 10 per cent over the period 1979-98). Thus, at the aggregate economy level, TFP growth-from both factor reallocation and increased firm efficiency-contributed 20 per cent to economic growth over the last two decades, lifting the growth rate by close to two percentage points.

Development of the TVE sector was uneven. In many east coast areas rural industries were well developed, but development in the central and west regions was lower and progressed more slowly. It is not likely to accelerate in the immediate future due to limitations in the supply of human capital and infrastructure. In general, the effect of institutional reform on rural industrialisation-and therefore on economic growthis diminishing. 
The TVE sector had absorbed 130 million of a total 450 million workers from the agricultural sector by 1998 . Another $60-70$ million migrated to cities, mainly in the 1990s, either permanently or temporarily (Wang forthcoming). However, there is still a large agricultural workforce-250260 million-sharing only 95 million hectares of farming land and with low labour productivity. Further reallocation of this labour is a potential source of economic growth in the future.

China's urbanisation is well below the world average. Its urban population only accounts for 30 per cent of the total population, lower than the average of other countries of the same income level by 10-15 per cent (SSB 1998). Due to lack of urban infrastructure and the heavy budgetary burden of urban residents' welfare provisions, the government encouraged rural industrialisation rather than urbanisation in the earlier stages of economic reform. Restrictions on rural-urban migration began to be eased only gradually since the late 1980 s. Further reduction of institutional barriers to labour mobility, policy promotion of urban infrastructure construction and urbanisation will be the stimulus for continued economic growth in the twenty-first century.

\section{Domestic savings and investment}

High domestic saving and investment rates have been an important source of economic growth in China. During the pre-reform period, total savings increased from 21 per cent to 38 per cent of GDP. They further increased during the reform period, to 41 per cent in 1997 (SSB 1998). Under the central planning system, the major source of investment was government revenue. The low efficiency of government investment restricted its contribution to economic growth. However, there have been three major changes in the investment pattern since reform. First, enterprises and individuals received a greater share of income. Government budgetary expenditure as a share of GDP declined from 31 per cent in 1978 to 22 per cent in 1985, and 12 per cent in 1997 (SSB 1998). ${ }^{6}$ Government investment decreased, but state and nonstate enterprise investment, either funded by banks or self-funded, increased dramatically. Second, the structure of budgetary expenditure changed, with provincial and local governments constituting a greater share. The share of central government in total budgetary expenditure declined from 47 per cent in 1978 to 40 per cent in 1985, and 27 per cent in 1997 (SSB 1998). Provincial and local governments are more 
market-oriented in their investment behaviour. Third, rapid increases in disposable incomes brought about a rise in household savings. There was a rise in savings rates of urban and rural residents in the reform period (Table 2.5). Banks replaced the government budget as the major suppliers of investment funds, and household savings became the major source of bank credit. Household savings accounted for only 25 per cent of total bank deposits in 1985, but this figure increased to 56 per cent in 1997 (Table 2.4).

High savings sustained high investment. Domestic investment in fixed assets (the major part of total domestic investment) is highly correlated with domestic savings (Figure 2.1). As a result of increases in the savings rate and market-oriented changes in the investment mechanism, the growth rate of total investment in fixed assets significantly increased in the reform period. It was 5.3 per cent on average in 1954-78 with large fluctuations, but accelerated to an average of 11.4 per cent in 1979-97 (both deflated to constant prices by the author).

A comparison of GDP growth rate with the growth rate of domestic investment in fixed assets in 1954-97 shows a close relationship between the two, suggesting that high levels of investment bring about high economic growth (Figure 2.2).

\section{Table 2.4 Change in sources of bank funds}

\begin{tabular}{ccccc} 
Year & $\begin{array}{c}\text { Total bank } \\
\text { deposit } \\
(100 \text { million yuan) }\end{array}$ & $\begin{array}{c}\text { Treasury and govt } \\
\text { agency deposit } \\
(\%)\end{array}$ & $\begin{array}{c}\text { Enterprise } \\
\text { deposit } \\
(\%)\end{array}$ & $\begin{array}{c}\text { Household } \\
\text { deposit } \\
(\%)\end{array}$ \\
1985 & 4,273 & 16.2 & & \\
1990 & 11,645 & 8.5 & 48.5 & 24.8 \\
1992 & 18,891 & 4.9 & 34.6 & 34.3 \\
1993 & 23,230 & 5.2 & 36.1 & 45.9 \\
1994 & 40,502 & 4.2 & 33.0 & 48.2 \\
1995 & 53,882 & 3.6 & 32.8 & 53.1 \\
1996 & 68,596 & 3.3 & 32.7 & 55.0 \\
1997 & 82,390 & - & 34.8 & 56.2 \\
\hline
\end{tabular}

Note: The different sources of deposit are as a percentage of total bank deposits. Data for 1993 and earlier years are that of the state banks. Source: Calculated from State Statistical Bureau, various years. Statistical Yearbook of China, China Statistical Publishing House, Beijing. 
In future years, the savings rate is likely to decrease due to changing consumption patterns of the younger generation and the increasing ratio of aged dependency (the proportion of aged people in the total population). However, a high investment rate is likely to be sustained in the coming decades, since there are no signs of domestic savings declining in the short run. High savings have led to a contraction in consumer demand in the late 1990s. This is explained by economists as a result of increasing uncertainty in people's future employment status, income and pensions, and increasing expenditures on housing, medical services and children's education. For urban residents, uncertainty has resulted from incompleteness of the reform of the employment, pension, housing, medical and education systems. The new systems may need a number of years to be completed, and may still provide less certainty than the old ones. For rural residents, uncertainty arises from large fluctuations in grain prices and the increasing burden of various unregulated fees and charges collected by local governments. Further reforms of the grain trade and government finance systems are needed, and the effectiveness of anti-corruption campaigns needs to be raised in the intermediate and long run.

\section{Table 2.5 Savings rates of rural and urban residents}

\begin{tabular}{|c|c|c|c|c|c|c|}
\hline & \multicolumn{3}{|c|}{ Urban residents } & \multicolumn{3}{|c|}{ Rural residents } \\
\hline & $\begin{array}{c}\text { Income } \\
\text { (yuan) }\end{array}$ & $\begin{array}{c}\text { Savings } \\
\text { (yuan) }\end{array}$ & Saving rate & $\begin{array}{c}\text { Income } \\
\text { (yuan) }\end{array}$ & $\begin{array}{c}\text { Savings } \\
\text { (yuan) }\end{array}$ & Saving rate \\
\hline $\begin{array}{l}1978 \\
1980\end{array}$ & .. & .. & .. & 134 & 116 & 13.4 \\
\hline 1981 & $50 \ddot{0}$ & $45 \ddot{7}$ & $8 . \ddot{6}$ & 223 & & \\
\hline 1985 & 739 & 673 & 8.9 & 398 & 317 & 20.4 \\
\hline 1990 & 1,510 & 1,279 & 15.3 & 686 & 585 & 14.7 \\
\hline 1994 & 3,496 & 2,851 & 18.4 & 1,221 & 1,017 & 16.7 \\
\hline 1995 & 4,283 & 3,538 & 17.4 & 1,578 & 1,310 & 17.0 \\
\hline 1996 & 4,839 & 3,919 & 19.0 & 1,926 & 1,572 & 18.4 \\
\hline 1997 & 5,160 & 4,186 & 18.9 & 2,090 & 1,617 & 22.6 \\
\hline
\end{tabular}

Notes: Income for rural residents is average net income per capita (for 1985 and earlier it is total income per capita); for urban residents it is average disposable income per capita. All are in current prices. The consumer price index in 1997 was about 350 per cent of 1978.

Source: Household surveys, in State Statistical Bureau, 1998. Statistical Yearbook of China, China Statistical Publishing House, Beijing. 


\section{Figure 2.1 Domestic savings and investment in fixed assets} as percentages of GDP

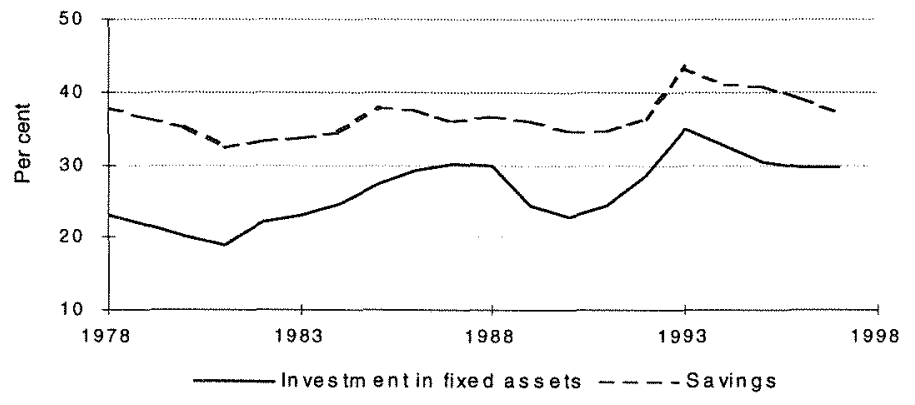

Note: Domestic investment in fixed assets = total investment in fixed assets foreign investment in fixed assets. Saving rates are based on GDP calculated using the expenditure method.

Source: Calculated from State Statistical Bureau, various years. Statistical Yearbook of China, China Statistical Publishing House, Beijing.

\section{Figure 2.2 Growth rates of GDP and domestic investment, 1954-97 (per cent)}

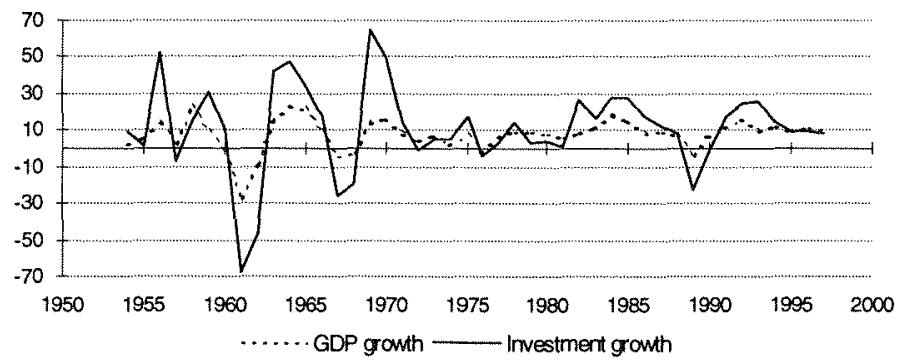

Note: Growth rates are calculated using 1980 constant prices as a base. The deflator used is a weighted combination of the producer price indexes of industrial products and the retail price indexes (weights $=0.5$ and 0.5 ).

Source: Calculated from State Statistical Bureau, various years. Statistical Yearbook of China, China Statistical Publishing House, Beijing. 


\section{Total factor productivity growth}

Numerous studies showed positive TFP growth in the industrial and agricultural sectors during the period of economic reform (World Bank 1985, 1997b; Chen et al. 1988a; Jefferson et al. 1992). Comparative studies of TFP changes between the pre-reform and reform periods have been done, and economic growth rates and TFP changes decomposed. Capital stock for the period of 1953-97 is derived based on: gross investment in fixed assets, decomposed by state and nonstate sectors; capital formation ratios, ${ }^{7}$ and price indices of investment in fixed assets.

Results of the calculation of total capital stock, domestic capital stock, and the total employment and GDP data for the period 1953-97 are provided in Appendix Table 2.2. Growth rates of factors and GDP are shown in Appendix Table 2.1.

Estimation results using a Cobb-Douglas production function and Cochrane-Orcutt for auto-correction, suggest that the capital and labour elasticities of GDP 0.52 and 0.48 , respectively (Appendix Table 2.3). The estimation results also indicate positive and significant effects from foreign direct investment, in addition to total capital, and a negative effect of inflation on economic growth. The regression suggests higher TFP growth in the reform than pre-reform period, but this could not be confirmed due to the statistic insignificance. The model specification and the results are provided in Appendix Table 2.3.

Due to a shortage of information about human capital accumulation, technical inputs, and effective measures for overall institutional changes, their effects on economic growth could not be directly estimated from the model. ${ }^{8}$ However, using estimated values of $\alpha$ and $\beta$, the effect of capital and labour on economic growth (input-driven growth) can be calculated. TFP growth can then be derived as the residual when the input-driven growth rate is subtracted from the actual economic growth rate, yielding

$$
g_{t}=\hat{Y}_{t}-\hat{Y}_{t}^{F}\left(K_{t}, L_{t}\right)=\hat{Y}_{t}^{F}-\alpha \hat{K}_{t}-(1-\alpha) \hat{L}_{t}
$$

where $Y_{t}, K_{t}, L_{t}$, and $Y_{t}^{F}$ are growth rates of GDP, capital stock, employment, and fitted input-driven growth rate at year $t$, respectively; $g_{1}$ is the TFP growth rate at year $t$. They are instantaneous growth rates, and are converted into annual growth rates later. $\alpha$ is the elasticity of capital. 
The TFP growth rate, $g_{t}$ is broadly defined since it includes all the effects of human capital accumulation, technological progressincluding new technology introduced through foreign direct investment (FDI)-and efficiency changes brought about by institutional and policy changes. Part of the effects of human capital growth and technical changes, excluding their spillover effect, could be defined as input-driven growth, as they result from investment in human capital and research and development.

The last column of Appendix Table 2.1 shows the calculated TFP changes for each year in the period 1954-97. The average growth rates of inputs, GDP and TFP for the pre-reform and reform periods are provided in Table 2.6. The table indicates a clear acceleration of TFP growth during the reform period, increasing from 1.8 to 2.5 percentage points. ${ }^{9}$ The growth rate of net capital stock increased dramatically, from an average of 4.2 per cent during the pre-reform period to 10.7 per cent after (Table 2.6). Labour growth increased by half a per cent due to high fertility rates in the pre-reform period. These two factors drove up the average economic growth rate by 3.5 percentage points. Actual GDP growth increased by 4.2 percentage points, to 9.5 per cent, ${ }^{10}$ with an 0.7 percentage point increase in TFP.

In this study the calculated growth rate of capital for the pre-reform period is significantly lower than some other calculations. It appears that this is the result of using the actual capital formation ratios for the calculation. The capital formation ratio was only 67 per cent on average in 1958-77, but increased to an average of 76 per cent in 1978-97. This indicates lower efficiency in capital investment in the pre-reform period. Thus, higher capital accumulation during the reform period not only resulted from an increase in savings, but also from more efficient use of investment funds. Institutional changes were also a contributing factor. The higher savings rate was partly due to institutional effectschanging incentive mechanisms for individuals' and firms' saving and investment behaviour.

Total factor productivity growth accounted for 27 per cent of the average growth rate in 1979-97 (Table 2.6). According to the estimations in Table 2.3, factor reallocation between the agricultural and TVE sectors contributed to 12 per cent of economic growth. Together with the excluded TFP growth in the two rural sectors, about 20 per cent of the TFP contribution-the major part-was from the rural sector. 
The remaining 6 per cent share of TFP in economic growth is likely attributable to the urban non-state sector, since the state sector was found to have either slight positive TFP growth, or none at all. In comparison to the TVE sector, the urban non-state sector is smaller, with a lower growth rate, but it experienced dramatic growth after 1992, particularly as a result of FDI. In contrast, the situation in the state sector worsened (Jefferson et al. 1992; Woo et al. 1994a).

The difference between actual GDP growth and fitted input-driven growth is the growth in TFP indicating large fluctuations in economic growth and an unstable TFP growth rate, particularly during the prereform period (Figure 2.3 and Appendix Table 2.1). The major growth fluctuations are explained by policy changes and political instability (see Table 2.7). For example, fluctuations in TFP growth were significant and positive in 1978-80, 1983-85 and 1992-94, when reform was accelerated, particularly in the rural sectors, but became negative in 1989-90, when the reform process was suspended. This indicates that TFP growth was mainly an effect of economic reform (institutional change induced rural industrialisation). Technological progress and human capital accumulation would have yielded a more stable trend in TFP growth, if they had been the major contributors to the higher economic growth rate.

The lower employment and output growth rate of the TVE sector in the 1990s show that the effect of institutional change on rural industrialisation is diminishing. Rural industrialisation will still be an important contributor to economic growth in the short to medium term,

Table 2.6 Input-driven growth and TFP changes in the prereform and reform periods (per cent)

$\begin{array}{lrrccc}\text { Year } & \begin{array}{c}\text { Capital } \\ \text { growth }\end{array} & \begin{array}{l}\text { Labour } \\ \text { growth }\end{array} & \begin{array}{c}\text { Actual GDP } \\ \text { growth }\end{array} & \begin{array}{c}\text { input-driven } \\ \text { growth }\end{array} & \text { TFP growth } \\ & & & & & \\ 1954-78 & 4.22 & 2.55 & 5.29 & 3.42 & 1.80(1.78) \\ 1979-97 & 10.69 & 2.93 & 9.51 & 6.90 & 2.46(2.43) \\ \text { Acceleration } & 6.47 & 0.38 & 4.22 & 3.48 & 0.66(0.65)\end{array}$

Note: Average TFP growth rates in parentheses are instantaneous growth rates; others are annual growth rates. 
however technological progress and human capital accumulation will become increasingly important means of sustaining high economic growth in the long run.

\section{Contribution of economic openness to growth performance}

China's economic growth performance also benefited from the economic openness of the market approach. During the reform period, the old self-sufficiency policy and the "heavy industry priority' development strategy were replaced by an 'open-door policy' - predominantly exportorientation based on China's comparative advantage of cheap labour, and the introduction of foreign investment and technology from abroad. Exports, the majority of which were labour-intensive goods, increased from US $\$ 18$ billion to 183 billion in 1980-97 (SSB 1998:621). Imports and exports accounted for only 9.8 per cent of GDP in 1978, whereas in 1997 , this figure was 36 per cent. The current account has been in surplus since 1990 (except 1993). Net exports accounted for 1.6 per cent of GDP on average in 1990-97 (see Table 2.8). In cases of

Figure 2.3 Actual GDP growth and input-driven growth, 19531997 (per cent)

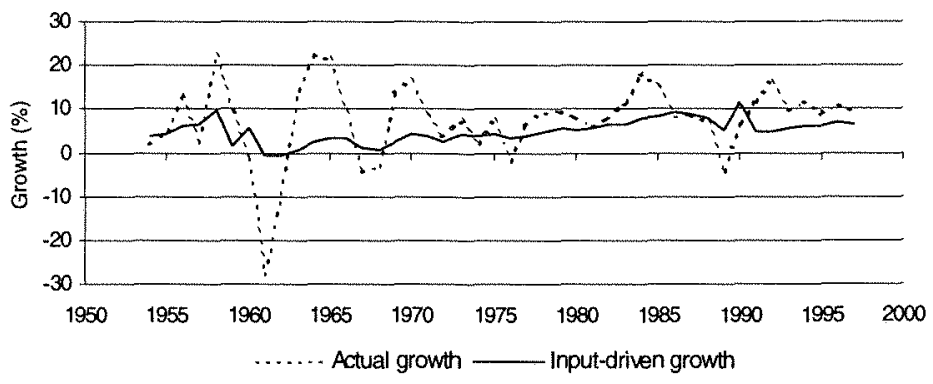

Source: Data from Appendix Table 2.1. 
Table 2.7 The impact of policy changes and political instability on economic growth

\begin{tabular}{|c|c|c|}
\hline Year & Policy & $\begin{array}{l}\text { Direction of } \\
\text { short run impact } \\
\text { on growth }\end{array}$ \\
\hline 1956 & $\begin{array}{l}\text { Introduction of } 156 \text { large investment } \\
\text { projects from the former Soviet Union }\end{array}$ & + \\
\hline 1957 & 'Anti rightwing' campaign & - \\
\hline $1958-59$ & 'Great Leap Forward' & + \\
\hline $1960-62$ & Disastrous failure of 'Great Leap Forward' & - \\
\hline $1963-65$ & Recovery from the disaster & + \\
\hline $1967-68$ & Beginning of 'Cultural Revolution' & - \\
\hline $1969-70$ & $\begin{array}{l}\text { Recovery from the early stages of } \\
\text { 'Cultural Revolution' }\end{array}$ & + \\
\hline 1976 & 'Refuting Deng' campaign & - \\
\hline 1981 & Contractionary macro policy & - \\
\hline $1983-85$ & Liberalisation of the rural non-state sectors & + \\
\hline $1989-90$ & Policy changes towards re-centralisation & - \\
\hline $1992-93$ & Restoring market-oriented reform & + \\
\hline
\end{tabular}

Sources: Ma, H., Liu, Z. and Lu, B. (eds), 1998. Report of China's

Macroeconomic Policy, China Finance and Economics Press, Beijing; Zhou, T.H., Wu, Z., Fu, F.X. and Gao, S.Q. (eds), 1984. Economic System Reform in Contemporary China, China Social Sciences Press, Beijing.

Table 2.8 Net exports as percentage of GDP (billion yuan)

$\begin{array}{lrrrrr}\text { Year } & \text { Exports } & \text { Imports } & \text { Net exports } & \text { GDP } & \text { Net exports/GDP (\%) } \\ & & & & & \\ 1990 & 299 & 257 & 41 & 1,855 & 2.2 \\ 1991 & 383 & 340 & 43 & 2,162 & 2.0 \\ 1992 & 468 & 444 & 23 & 2,664 & 0.9 \\ 1993 & 529 & 599 & -70 & 3,464 & -2.0 \\ 1994 & 1,042 & 996 & 46 & 4,676 & 1.0 \\ 1995 & 1,245 & 1,105 & 140 & 5,848 & 2.4 \\ 1996 & 1,257 & 1,156 & 102 & 6,859 & 1.5 \\ 1997 & 1,516 & 1,182 & 335 & 7,477 & 4.5 \\ \text { Average } & & & & & 1.6\end{array}$

Note: In current prices.

Source: State Statistical Bureau, 1997, 1998. Statistical Yearbook of China, China Statistical Publishing House, Beijing. 
insufficient domestic demand, net exports contributed as much as 1.6 percentage points to the economic growth rate. This figure could have been even higher in 1997 and 1998, as net exports accounted for a significantly higher percentage of GDP.

FDI was another important contributor to economic growth in the 1990s. It increased rapidly, from US $\$ 1.3$ billion in 1984 to 4.4 billion in 1991, and then 45 billion in 1997. In Table 2.9, the calculated capital stock is provided and decomposed into local capital and foreign capital (from FDI); their contribution to capital growth and economic growth have been calculated. Foreign capital accounted for 5.5 per cent of total capital stock in 1991, and increased to 11.1 per cent in 1997.

Using the estimated elasticity of capital $(\alpha=0.5)$, the direct contribution of foreign capital to the economic growth rate is derived as 0.2 and 0.5 percentage points in the two sub periods 1979-92 and 1993-97, respectively. For the entire period, it accelerated economic growth by an average of 0.3 percentage points (see Table 2.9).

The production function estimation also suggests that an additional 1.3 percentage points is contributed to the economic growth rate by every 10 per cent share of foreign capital in total capital stock (see coefficient $\gamma$ in Appendix Table 2.3). This partly arises from better technology brought by $\mathrm{FDI}$, and partly from the spillover effects on technology, management skills, and the pressure of market competition on local firms to increase efficiency (this may be called a spillover effect of institutional reform). For simplicity, these effects are together called the spillover effect. The estimated spillover effect may be further confirmed, however, it is significant at the one per cent level. According to this estimation, its contribution to the economic growth rate was minor in the 1980s and early 1990s: only 0.3 percentage points in 1979-92 on average, but increased rapidly to 0.9 on average in 1993-97, higher than its direct contribution (see Table 2.9). As the sum of its direct contribution and the spillover effect, total contribution of foreign capital to the economic growth rate in the two sub-periods was 0.5 and 1.4 percentage points, respectively. Its total contribution could reach 2.2 percentage points in 1997, a share of 24 per cent of economic growth.

Due to the East Asian financial crisis and the lower economic growth rate in China, capital inflow will be slower in the near future. In 1998, FDI in China remained at 1997 levels. If this trend continues over the next three to four years, the contribution of foreign capital to the economic growth rate will fall by $0.2-0.3$ percentage points each year, and will diminish from three to two percentage points. 


\section{Conclusion}

China's economic growth significantly accelerated during the last two decades of economic reform, reaching an average of 9.5 per cent. Growth was predominantly due to a higher rate of capital formation. Growth of capital and labour contributed 6.9 percentage points, or 73 per cent of total economic growth, during the period 1979-97. The higher growth of capital was due to higher savings and investment, the results of decentralisation in income distribution and marketoriented changes to create greater incentives to invest. The capital formation ratio increased from an average of 67 per cent in the prereform period to 76 per cent. This means more efficient use of investment funds, particularly in the non-state sector. FDI played an important role, but only after 1992.

Table 2.9 Contribution of foreign capital to economic growth

\begin{tabular}{|c|c|c|c|c|c|}
\hline \multirow[t]{2}{*}{$\begin{array}{c}\text { Total } \\
\text { capital }\end{array}$} & \multicolumn{2}{|c|}{$\begin{array}{l}\text { Contribution to } \\
\text { capital stock } \\
\text { and growth }\end{array}$} & \multirow[t]{2}{*}{$\begin{array}{c}\text { Economic } \\
\text { growth }\end{array}$} & \multicolumn{2}{|c|}{$\begin{array}{l}\text { Contribution to } \\
\text { economic growth } \\
\text { by foreign capital }\end{array}$} \\
\hline & $\begin{array}{l}\text { Local } \\
\text { capital' }\end{array}$ & $\begin{array}{l}\text { Foreign } \\
\text { capital }^{t}\end{array}$ & & $\begin{array}{l}\text { Direct } \\
\text { effect }\end{array}$ & $\begin{array}{c}\text { Spillover } \\
\text { contribution }\end{array}$ \\
\hline
\end{tabular}

Stock (billion yuan, 1980 prices)

$\begin{array}{lrrrrrr}1978 & 534 & 100 & - & . . & . . & . . \\ 1992 & 2,141 & 95.1 & 4.9 & . . & . . & . . \\ 1997 & 3,679 & 90.7 & 9.3 & . . & . . & . . \\ \text { Growth (\%) } & & & & & & \\ 1954-78 & 4.2 & 4.2 & - & 5.3 & - & . \\ 1979-97 & 10.7 & 10.1 & 0.6 & 9.5 & 0.3 & 0.6 \\ 1979-92 & 10.4 & 10.0 & 0.4 & 9.2 & 0.2 & 0.3 \\ 1993-97 & 11.4 & 10.4 & 1.0 & 10.3 & 0.5 & 0.9\end{array}$

Notes: 'Local capital and foreign capital (formed from FDI) are calculated as percentages of total capital stock and the percentage points contribution to the growth rate of total capital. Direct contribution of foreign capital to economic growth is calculated on the assumption that foreign capital is indifferent from local capital. Any possible contribution from higher technology and the spillover of technology and management skill are included under 'spillover effect'.

Source: Calculated from Appendix Table 2.1 and State Statistical Bureau, various years. Statistical Yearbook of China, China Statistical Publishing House, Beijing. 
Changes in TFP were the other important source of economic growth, constituting the remaining 2.6 percentage points, or 27 per cent of total economic growth. Compared with the pre-reform period, TFP growth increased from an average of 1.8 per cent to 2.5 per cent.

A major reason for TFP growth was institutional change, mainly those that encouraged rural industrialisation. This effect contributed 14 per cent to economic growth over the period 1979-92, but fell to 8 per cent during 1993-97. Together with the excluded TFP changes in the rural sectors, rural development contributed to about 20 per cent of economic growth and was the major part of TFP contribution.

Technological progress and efficiency increases at the firm level played a minor role in TFP changes from 1979 to 1992, but have become more important in recent years. Nine per cent of changes in TFP came from FDI due to better technology and spillover effects. The remaining 11 per cent was likely due to short-run effects, part of which may be the result of overstatement of economic growth rate.

The role of FDI is becoming increasingly important. FDI accounted for 15 per cent of total investment in fixed assets in 1996 and 1997

Table 2.10 Decomposition of economic growth by contributors (per cent)

Share of total contribution Contribution to growth rate $\begin{array}{llll}1979-92 & 1993-97 & 1979-97 & 1979-97\end{array}$

\begin{tabular}{|c|c|c|c|c|}
\hline $\begin{array}{l}\text { GDP growth rate } \\
\text { Share of } \\
\text { contribution }\end{array}$ & 9.2 & 10.3 & 9.5 & 9.5 \\
\hline Input-driven & 77 & 63 & 73 & 6.9 \\
\hline Labour & 19 & 6 & 15 & 1.4 \\
\hline Capital & 58 & 57 & 58 & 5.5 \\
\hline Foreign capital & 2 & 5 & 3 & 0.3 \\
\hline 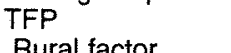 & 23 & 37 & 27 & 2.5 \\
\hline $\begin{array}{l}\text { reallocation } \\
\text { Technology and }\end{array}$ & 14 & 8 & 11 & 1.0 \\
\hline efficiency & 9 & 29 & 16 & 1.5 \\
\hline Foreign capital & 3 & 9 & 6 & 0.7 \\
\hline Total contribution & 100 & 100 & 100 & 9.5 \\
\hline
\end{tabular}

Sources: Tables 2.3, 2.6 and 2.9, and Appendix Tables 2.1 and 2.2. 
(calculated using current exchange rate). As a source of both inputdriven and TFP induced growth, foreign capital contributed to 14 per cent of economic growth in 1993-97, but 24 per cent in 1997. Recently FDI has replaced the TVE sector as the main engine of economic growth.

Foreign trade, particularly exports, was another important contributor to economic growth, especially in the 1990s. It has been important for maintaining economic growth in the short term since aggregate demand in the domestic market has been insufficient in recent years. In the long run a relatively large foreign trade sector will enable the economy to maintain its competitiveness in the world market, and allow transfer of new technologies to the domestic sector (Feder 1983). The East Asian financial crisis caused FDI and export growth to stagnate.

The three most important engines of growth-domestic investment and capital formation, rural industrialisation and FDI-will continue to play important roles in the future, although the latter two may not maintain the strong performance of recent years. A relatively high economic growth rate can be sustained in the coming decades, although without new sources of growth, this rate will be lower than in the past 20 years.

In the future, three factors may become more important in China's economic growth. The first is the acceleration of urbanisation, which will continue to bring China's abundant rural labour into non-agricultural sectors, with increasing efficiency in factor allocation. Economic efficiency will also be improved through economies of scale and urban externalities. The second factor is further industrial reform and structural adjustment, which will increase firms' efficiency and create incentives for technical innovation and adoption. Finally, but perhaps most important in the long run, is research and development (R\&D) and education. Realisation of some or all of these potential growth factors will see China's high economic growth continue for another two decades. 


\section{Appendix Table 2.1 Input-output growth and TFP growth, 1954-97 (per cent)}

\begin{tabular}{|c|c|c|c|c|c|}
\hline Year & Capital & $\begin{array}{l}\text { Labour } \\
\text { growth }\end{array}$ & $\begin{array}{c}\text { GDP } \\
\text { growth }\end{array}$ & Input driven & TFP growth \\
\hline 1953 & 5.61 & 3.06 & & 4.33 & \\
\hline 1954 & 5.92 & 2.19 & 1.90 & 4.04 & -2.05 \\
\hline 1955 & 6.09 & 2.27 & 4.89 & 4.16 & 0.70 \\
\hline 1956 & 8.97 & 3.09 & 12.97 & 5.99 & 6.58 \\
\hline 1957 & 9.71 & 3.27 & 2.36 & 6.44 & -3.84 \\
\hline 1958 & 7.37 & 11.90 & 22.13 & 9.61 & 11.43 \\
\hline 1959 & 8.92 & -5.36 & 9.12 & 1.53 & 7.47 \\
\hline 1960 & 8.95 & 2.81 & -1.79 & 5.84 & -7.21 \\
\hline 1961 & -0.53 & -1.12 & -27.94 & -0.82 & -27.34 \\
\hline 1962 & -2.43 & 1.25 & -9.24 & -0.61 & -8.69 \\
\hline 1963 & -1.12 & 2.82 & 14.04 & 0.83 & 13.10 \\
\hline 1964 & 0.85 & 4.11 & 22.42 & 2.47 & 19.47 \\
\hline 1965 & 3.81 & 3.37 & 21.30 & 3.59 & 107.10 \\
\hline 1966 & 2.52 & 3.96 & 9.18 & 3.24 & 5.75 \\
\hline 1967 & -1.09 & 3.39 & -4.37 & 1.12 & -5.43 \\
\hline 1968 & -2.10 & 3.57 & -2.96 & 0.69 & -3.63 \\
\hline 1969 & 0.59 & 4.10 & 13.72 & 2.33 & 11.12 \\
\hline 1970 & 5.29 & 3.63 & 16.48 & 4.46 & 11.51 \\
\hline 1971 & 4.30 & 3.45 & 8.47 & 3.87 & 4,43 \\
\hline 1972 & 4.05 & 0.66 & 3.99 & 2.34 & 1.61 \\
\hline 1973 & 6.31 & 2.23 & 7.41 & 4.25 & 3.03 \\
\hline 1974 & 5.33 & 1.96 & 2.03 & 3.63 & -1.55 \\
\hline 1975 & 6.61 & 2.14 & 7.22 & 4.35 & 2.75 \\
\hline 1976 & 4.62 & 1.74 & -2.08 & 3.17 & -5.09 \\
\hline 1977 & 6.44 & 1.40 & 6.64 & 3.89 & 2.65 \\
\hline 1978 & 7.78 & 1.97 & 9.13 & 4.83 & 4.10 \\
\hline 1979 & 8.76 & 2.17 & 9.52 & 5.41 & 3.89 \\
\hline 1980 & 6.94 & 3.26 & 8.43 & 5.08 & 3.19 \\
\hline 1981 & 7.73 & 3.22 & 6.25 & 5.45 & 0.76 \\
\hline 1982 & 9.26 & 3.59 & 7.96 & 6.39 & 1.48 \\
\hline 1983 & 10.53 & 2.52 & 11.29 & 6.45 & 4.54 \\
\hline 1984 & 12.17 & 3.79 & 18.33 & 7.90 & 9.67 \\
\hline 1985 & 13.31 & 3.48 & 14.95 & 8.28 & 6.16 \\
\hline 1986 & 16.50 & 2.83 & 8.45 & 9.45 & -0.91 \\
\hline 1987 & 14.60 & 2.93 & 8.99 & 8.61 & 0.35 \\
\hline 1988 & 12.96 & 2.94 & 6.82 & 7.83 & -0.94 \\
\hline 1989 & 8.71 & 1.83 & -4.15 & 5.21 & -8.90 \\
\hline 1990 & 8.07 & $15.51^{\mathrm{b}}$ & 6.45 & 11.72 & -4.72 \\
\hline 1991 & 8.10 & 1.39 & 11.56 & 4.69 & 6.56 \\
\hline 1992 & 8.77 & 1.17 & 16.16 & 4.90 & 10.74 \\
\hline 1993 & 9.85 & 1.25 & 9.75 & 5.46 & 4.06 \\
\hline 1994 & 11.02 & 1.24 & 11.97 & 6.02 & 5.61 \\
\hline 1995 & 11.38 & 1.11 & 8.89 & 6.12 & 2.61 \\
\hline 1996 & 12.98 & 1.33 & 11.11 & 6.99 & 3.85 \\
\hline 1997 & 11.99 & 1.09 & 9.87 & 6.40 & 3.26 \\
\hline \multicolumn{6}{|c|}{ Average rate } \\
\hline $1954-97$ & 6.97 & 2.72 & 7.10 & 4.82 & $2.17(2.15)^{\mathrm{z}}$ \\
\hline
\end{tabular}

Notes: anstantaneous growth rate; ${ }^{\text {b }}$ High employment here is the result of data adjustment by the State Statistical Bureau according to 1990 national census.

Source: Calculated from Appendix Table 2.2 and the estimated values of $\alpha$ and $\beta$. 


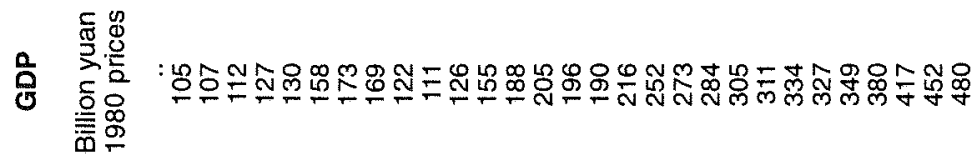

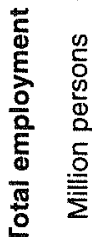

$$
\begin{aligned}
& \text { ⿷匚⿳亠口冋丁 } \\
& \text { 옹 }
\end{aligned}
$$

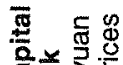

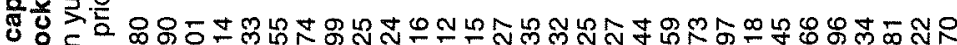

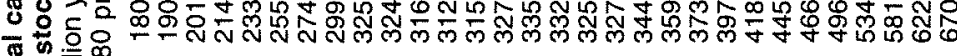

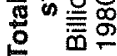

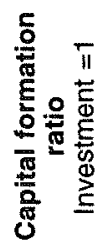

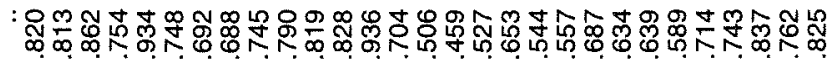
00000000000000000000000000000

: m

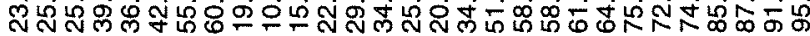

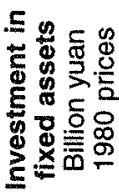




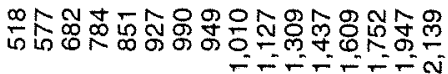

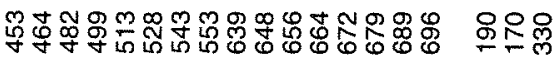

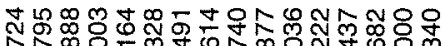
NN⿻ 0 m

Nด้

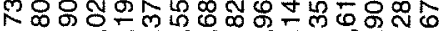
옹용요

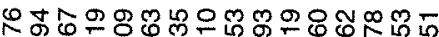

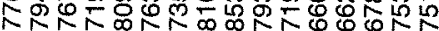
ல்

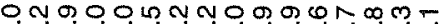

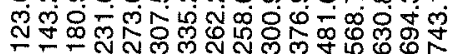
每

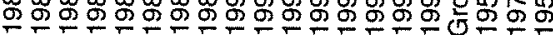

옳유욤

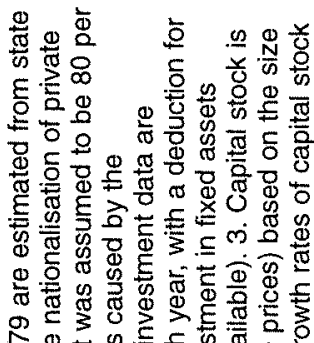

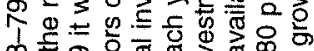

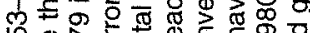

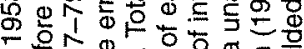

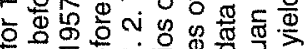
बढं

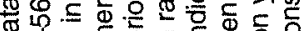

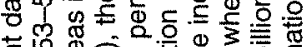

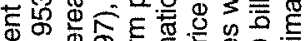

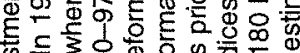
政 $\leq 30 \%$

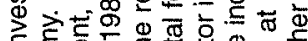
= $\Phi$ \% 丞

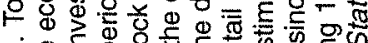

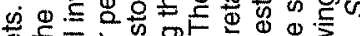
要

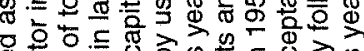

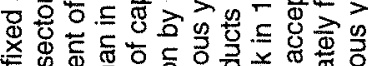

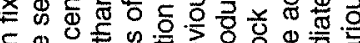

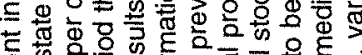
등 뜽은 क

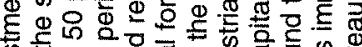

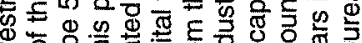

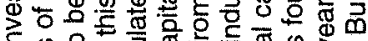

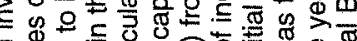

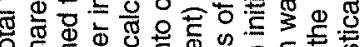
은

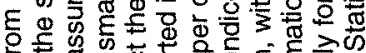

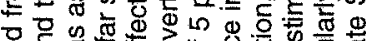

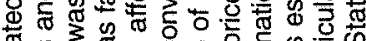

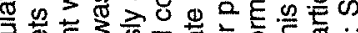

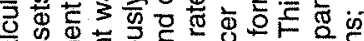
क .

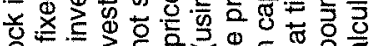

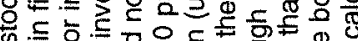

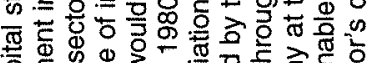
잉

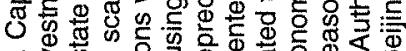
$\therefore$ के

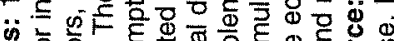

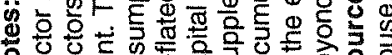

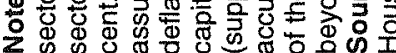


Appendix Table 2.3 Estimation result (Cochrane-Orcutt regression)

$\begin{array}{lcrrrr}\text { Variable } & \text { Coefficient } & \text { Value } & \text { Std Err } & T & \text { P>lt| } \\ \mathrm{kl} & & & & & \\ \mathrm{F} & \mathrm{a} & 0.5204 & 0.2683 & 1.940 & 0.060 \\ \mathrm{p} & \mathrm{g} & 13.028 & 4.8710 & 2.675 & 0.011 \\ \mathrm{~T}_{1} & \mathrm{~d} & -0.9608 & 0.2314 & -4.153 & 0.000 \\ \mathrm{~T}_{2} & \mathrm{~g}_{1} & 0.0257 & 0.0077 & 3.328 & 0.002 \\ & \mathrm{~g}_{2} & 0.0031 & 0.0275 & 0.111 & 0.912\end{array}$

Number of obs $=42$

$F(5,36)=58.75$

Prob $>F=0.0000$

Dependent variable: $y$ l

Adj $R^{2}=0.8757$

Notes: $y|=\ln Y-\operatorname{lnL}, k|=\mid n K-\ln L$, and $p=\ln P$.

Estimation of production function

The effects of different factors on economic growth are estimated by the following assumed production function

$$
Y=A_{0} e^{g_{1} T_{1}+g_{2} T_{2}} K^{\alpha} L^{1-\alpha} e^{\gamma F} P^{\delta}
$$

To take the logarithm form and impose the restriction of constant returns to scale, the model becomes

$$
\ln Y-\ln L=\ln A_{0}+g_{1} T_{1}+g_{2} T_{2}+\alpha(\ln K-\ln L)+\gamma F+\delta \ln P
$$

where $Y, K, L, P$ are GDP, capital stock, employment, and inflation rate (initial year $=1$ ) respectively; $F$ is the ratio of foreign capital to total capital; $T_{1}$ and $T_{2}$ are two time trends for the entire (pre-reform and reform) period and the reform period respectively $\left(T_{1}=0,1,2,3 \ldots\right.$, and $T_{2}=0,0,0, \ldots 1(\mathrm{~s}), 2, \ldots$; where $s$ is the first year of economic reform, 1978). $A_{0}$ is initial TFP; $g_{1}$ and $g_{1}+g_{2}$ are TFP growth rates for the pre-reform and reform periods, respectively. $\alpha$ is the capital elasticity of GDP. Data are for the period 1953-97. To rectify the auto-correction, the model is estimated using the CochraneOrcutt iterative process.

Sources: Estimation result; data calculated from Appendix Table 2.2 and State Statistical Bureau, 1998. Statistical Yearbook of China, China Statistical Publishing House, Beijing. 


\section{Notes}

'Some economists suggest an overstatement of the economic growth rate by one to two percentage points in the reform period (World Bank 1997d). This is possible, however the reasons may be more complex than which deflator was chosen. The author used the method suggested by the World Bank (1997d) and obtained an only slightly lower growth rate than the official statistics. Further investigation is needed. Even if the growth statistics for the reform period were overstated, economic performance was far better than during the pre-reform period, in which growth figures were at least equally overstated.

${ }^{2}$ See Solow (1956), Lucas (1988) and Romer (1986) for growth theories, and World Bank (1993b), Krugman (1994) and Martellaro (1996) for the current debates on East Asia and China's economic growth.

${ }^{3}$ The TVE sector includes nearly the entire rural non-agricultural sector with a major part being industry ( 60 per cent of TVE employment in 1997). It also includes a negligible agricultural contribution (1.5 per cent of TVE employment in 1997).

${ }^{4}$ This was also true at the early stages of the reform period. Using 1980-82 data from a case study, Chang (1993) found a negative and significant relationship between the share of TVE employment in rural labour and per capita state quota for grain production. In the study, this relationship became insignificant in 1983-85.

${ }^{5}$ Gross contribution of a sector to economic growth is simply the sector's share in economic growth, but a net contribution means it accelerates economic growth. If two sectors have the same marginal product of a factor, reallocating this factor from one sector to another would increase the gross contribution of one sector to growth but decrease it in another and the net contribution could be zero.

${ }^{6}$ There were increases in the non-budgetary revenues and expenditures of local governments, which more or less moderated the declining trend of government share of GDP. 
${ }^{7}$ The capital formation ratio for year $t$ is the ratio between the value of newly formed fixed assets and total investment in fixed assets at year t. Before 1980 it was calculated for the state sector as a weighted average for the state and non-state (collective) sectors for 198094, and for the overall economy afterwards. The capital formation ratio was higher in the reform than the pre-reform period. It has also increased more in the non-state sector than the state sector sine the late 1980s (see Appendix 2.2).

${ }^{8}$ The World Bank (1997d) suggests a positive contribution of workers' schooling to economic growth. However, the historical data for schooling are limited. Using the same method as the World Bank, the author obtained an insignificant result for schooling.

${ }^{9}$ The World Bank (1997d) estimated higher TFP growth for a similar period. This is likely to be the result of different estimations of capital stock and its growth rates.

${ }^{10} \mathrm{GDP}$ growth rate is derived from current price data and deflated into constant price data using a weighted deflator (see note in Figure 2.2). It is slightly lower than the growth rate provided by the State Statistical Bureau. 